5. Trung tâm Kiểm soát bệnh tật tỉnh Yên Bái. Báo cáo công tác Kiểm soát bệnh tật năm 2020 và phương hướng nhiệm vụ năm 2021. 2020.

6. Bvochora, T., et àl., Enhanced adherence counselling and viral load suppression in HIV seropositive patients with an initial high viral load in Harare, Zimbabwe: Operational issues. PLoS One, 2019. 14(2): p. e0211326.

7. Phạm Xuân Sáng and Phan Thị Thu Hương, Thực trạng và các yếu tố liên quan đến tuân thú điều trị $A R V$ của bệnh nhân tại các phòng khám ngoại trú của tỉnh Điện Biên nằm 2016. Tạp chí Y học dự phòng, 2017. 27(2(190)).

8. Phan Thị Thu Hương, Tuân thủ điêu trị $A R V$ và các yếu tố liên quan trên bênh nhân AIDS đang được điều trị tại trung tâm phòng chống HIV/AIDS tỉnh Hải Dương, năm 2016. Tạp chí Y học dự phòng, 2017. 27(3): p. 194-197.

9. Awungafac, G., et al., Viral load testing and the use of test results for clinical decision making for HIV treatment in Cameroon: An insight into the clinic-laboratory interface. PLoS One, 2018. 13(6): p. e0198686.

\title{
KẾT QUẢ ĐIỀU TRI UNG THƯ VÒM MŨI HỌNG GIAI ĐOẠN MUỘN BẰNG PHÁC ĐỒ GEMCITABINE - CISPLATIN TẠI BỆNH VIỆN K
}

\section{TÓM TẮT}

Mục tiêu: Đánh giá đáp ứng điều trị và một số tác dung không mong của phác đồ gemcitabine- cisplatin trên nhóm bệnh nhân nghiên cứu. Đối tượng và phương pháp nghiên cứu: Nghiên cứu mổ tả hồi cứu kết hợp với tiến cứu. Có 33 bệnh nhân ung thư vòm giai đoạn muộn được điều trị bước một bằng gemcitabine - cisplatin tại Bệnh viện $K$ từ tháng 1/2018 đến tháng 7/2021, bệnh nhân được đánh giá mức độ đáp ứng theo "Tiêu chuẩn Đánh giá Đáp ứng cho U đặc" (RECIST), độc tính theo tiêu chuẩn CTCAE 5.0. Kết quả: Đáp ứng: Tỉ lệ đáp ứng của phác đồ là 83,9 \%. Trung vị thời gian sổng thêm bệnh không tiến triển là 8,9 tháng. Độc tính: Các tác dung phụ hay gặp bao gồm: hạ bach cầu trung tính $(60.6 \%)$, hạ huyết sắc tố $(90,9 \%)$, nôn buồn nôn $(51.5 \%)$, chủ yếu là độc tính độ I, II. Kết luận: Phác đồ gemcitabine cisplatin cho bệnh nhân ung thư vòm mũi họng tỷ lệ đáp ứng cao, độc tính chủ yếu lên hệ huyết học, dung nạp tốt.

Tư khóa: ung thư vòm mũi họng, giai đoạn tái phát, di căn

\section{SUMMARY \\ EFFICACY OF GEMCITABINE -CISPLATIN IN METASTATIC NASOPHARYNGEAL CANCER PATIENTS IN VIETNAM NATIONAL CANCER HOSPITAL}

Objectives: The aims of our study were to investigate the activity and toxicity of gemcitabine cisplatin regimen in metastatic nasopharyngeal cancer patients. Patients and Methods: Clinical trial, retrospective study. From January 2018 to July 2021,

\footnotetext{
${ }^{1}$ Trường Đại học Y Hà Nội

²Bênh viên $K$ Tân Triều

Chịu trách nhiệm chính: Nguyễn Thị Phương Anh

Email: phuonganhhmu95@gmail.com

Ngày nhân bài: 28.7.2021

Ngày phản biện khoa học: 29.9.2021

Ngày duyệt bài: 4.10.2021
}

\section{Nguyễn Thị Phương Anh ${ }^{1}$, Đỗ Hùng Kiên ${ }^{2}$}

we enrolled 33 metastatic nasopharyngeal cancer patientsin Vietnam National Cancer Hospital. All patients received combination of gemcitabine and cisplatin. Tumor response rateand toxicitys were determined. Results: Response rate: Overal response rate was $83,9 \%$. Median progression free survival was 8,9 months. Toxicity: Most adverse events were manageable and tolerable. The most common was neutropenia $(60.6 \%)$, anaemia $(90.9 \%)$, vomiting and nausea (51.5\%), most of them were grade 1 and grade 2. Conclusion: Gemcitabine cisplatin regimen in metastatic nasopharyngeal cancer patients is high repsond rate and tolerable.

Key words: Nasopharyngeal cancer, recurrent, metastatic stages

\section{I. ĐĂT VẤN ĐỀ}

Ung thư vòm mũi họng (UTVMH) là bệnh lý ác tính có nguồn gốc từ biểu mô vòm mũi họng, là một trong những ung thư phổ biến vùng đầu cổ. Tại Việt Nam, UTVMH đứng thứ 9 về tỉ lệ mới mắc, và thứ 7 về tỉ lệ tử vong ở cả 2 giới, có thể gặp 2 đỉnh tuổi: 15-24 tuổi và độ tuổi 45-60, nam mắc nhiều hơn nữ với một số yếu tố nguy cơ: virut EBV, chế độ ăn, chủng tộc, di truyền [1], [2], [3].

UTVMH giai đoạn muộn (di căn nguyên phát và tái phát di căn xa) thường có tiên lượng xấu, trung vị sống thêm khoảng 10-15 tháng [4], [5]. Điều trị UTVMH giai đoạn muộn, hóa trị nền tảng platinum đóng vai trò chủ đạo. Trong nhiều thập niên, phác đồCisplatin-5FUđược sử dụng rộng rãi điêu trị UTVMH giai đoạn tái phát, di căn, mặc dù trước đó chưa có bằng chứng chứng tó phác đồ nào có ưu thế hơn trong điều trị. Năm 2016, trong nghiên cứu của Li Zhang và cộng sự, phối hợp Gemcitabine và Cisplatin trong điều trị bước 1 UTVMH giai đoạn tái phát, di căn có tỉ lệ đáp ứng (RR), thời gian sống thêm bệnh không tiến 
triển (PFS), sống thêm toàn bô (OS) cao hơn so hẳn so với phác đồ tiêu chuẩn cisplatin - $5 \mathrm{FU}$ trước đó. Phác đồ gemcitabine-cisplatin cũng dung nạp tốt hơn mặc dù các tác dụng phụ lên huyết học là cao hơn so với phác đồ $\mathrm{CF}$ [6]. Từ đó, gemcitabine-cisplatin trở thành phác đồ tiêu chuẩn lựa chọn ưu tiên trong điều trị bước 1 UTVMH giai đoạn muộn. Phác đồ đã được áp dụng điều trị ở nhiều nước trên thế giới cũng như tại Việt Nam. Tại bệnh viện $K$, phác đồ đã được áp dụng trong thực hành lâm sàng trong những năm gần đây. Cho đến nay, chưa có nghiên cứu nào trong nước được thực hiện để đánh giá kết quả điêu trị của phác đồ này. Chính vì vậy chúng tôi thực hiện nghiên cứu với mục tiêu sau: "Đánh giá đáp ứng điều trị và một số tác dụng không mong của phác đồ gemcitabinecisplatin ở các bệnh nhân UTVMH giai đoạn muộn".

II. ĐỐI TƯợNG VÀ PHƯƠNG PHÁP NGHIÊN CỨU

1. Đối tượng nghiên cứu. Bệnh nhân có chẩn đoán xác định là ung thư vòm mũi họng giai đoạn muộn, được điều trị bằng phác đồ gemcitabine-cisplatin, tại bệnh viện $K$ từ $1 / 2018$ đến $7 / 2021$.

Tiêu chuẩn lựa chọn: Các bệnh nhân UTVMH giai đoạn muộn (di căn M1 ) theo AJCC 2017, có bằng chứng mô bệnh học là UTVMH chưa điều trị hóa chất trước đó, chỉ số toàn trạng từ $0-1$, có tổn thương đích đánh giá được theo tiêu chuẩn RECIST 1.1 [7], được điều trị ít nhất 3 chu kì gemcitabine - cisplatin và được theo dõi sau điều trị.

Tiêu chuẩn loại trừ: Bệnh nhân mắc các bệnh cấp tính đe dọa tính mạng, hoặc các bệnh nhân có di căn thần kinh trung ương, phụ nữ có thai, bệnh nhân mắc ung thư thứ 2 .

2.Phương pháp nghiên cứu

Thiết kế nghiên cứu: Nghiên cứu mô tả hồi cứu kết hợp tiến cứu.
Cõ̃ mẫu và cách chọn: Chọn mẫu thuận tiện, 33 bệnh nhân đủ tiêu chuẩn lựa chọn, được điều trị tại bệnh viện $K$ từ tháng $1 / 2018$ đến tháng $7 / 2021$.

Phác đồ điêuu trị: Phác đồ gemcitabine cisplatin: Gemcitabine $1000 \mathrm{mg} / \mathrm{m} 2$ da truyền tĩnh mạch trong 30 phút ngày 1 và ngày 8 , Cisplatin $80 \mathrm{mg} / \mathrm{m} 2$ da truyền tĩnh mạch trong 4 giờ ngày 1 . Chu kì điều trị 21 ngày.

Đánh giá độc tính của phác đồ: Độc tính trên huyết học, độc tính ngoài huyết học (Theo NCI-CTCAE 5.0).

Đánh giá đáp ứng điêu trị: sau 3-6 chu kì, theo RECIST 1.1 [7] gồm: Đáp ứng hoàn toàn, đáp ứng 1 phần, bệnh ổn định, bệnh tiến triển.

Xử lý số liệu: nhập số liệu, làm sach, mã hoá số liệu: sử dụng phần mềm SPSS 20 và các test thống kê y học.

Đạo đức nghiên cứu: Trung thực trong thu nhập số liệu

\section{KẾT QUẢ NGHIÊN CỨU}

\section{Một số đặc điểm của đối tượng nghiên} cứu. Kết quả cho thấy trong tổng số 33 bệnh nhân tham gia nghiên cứu, nam giới chiếm tỉ lệ $81,8 \%$, nữ giới chiếm tỉ lệ $18,2 \%$. Tỉ lệ nam/nữ là $9 / 2$.

Tuổi trung bình của đối tượng nghiên cứu là $51,6 \pm 11,1$, thấp nhất là 23 tuổi, cao nhất là 70 tuổi.

Tỉ lệ bệnh nhân giai đoạn di căn nguyên phát chiếm $39,4 \%$ và ở giai đoạn tái phát di căn là $60,4 \%$.

Triệu chứng lâm sàng hạch cổ $(39,4 \%)$ thường gặp, các triệu chứng cơ quan di căn xa ít gặp hơn, 30,3\% bệnh nhân không có triệu chứng.

Trong các vị trí di căn: di căn phổi, hạch, xương thường gặp chiếm lần lượt 45,5\%, $39,4 \%, 36,4 \%$, di căn gan ít gặp hơn chiếm $27,3 \%$. Đa phần bệnh nhân di căn 1 hoặc 2 cơ quan là $97 \%$, một bệnh nhân di căn 3 cơ quan.

\section{2. Đánh giá kêt quả điều trị}

Bảng 1. Tỉ lệ đáp ứng và một số yêu tố liên quan

\begin{tabular}{|c|c|c|c|c|c|c|c|}
\hline \multirow{2}{*}{\multicolumn{2}{|c|}{ Các y }} & \multicolumn{3}{|c|}{ Sau 3 chu kỳ } & \multicolumn{3}{|c|}{ Sau 6 chu kỳ } \\
\hline & & \multirow{2}{*}{$\begin{array}{l}\text { Đáp ứng } \\
9(69,2 \%)\end{array}$} & \multirow{2}{*}{$\begin{array}{c}\begin{array}{c}\text { Không đáp } \\
\text { ứng }\end{array} \\
4(30,8 \%)\end{array}$} & \multirow{3}{*}{$\begin{array}{c}\mathbf{P} \\
>0,05\end{array}$} & \multirow{2}{*}{$\begin{array}{c}\text { Đáp ứng } \\
10(90,9 \%)\end{array}$} & \multirow{2}{*}{\begin{tabular}{|c|}
$\begin{array}{c}\text { Không đáp } \\
\text { ứng }\end{array}$ \\
$1(9,1 \%)$ \\
\end{tabular}} & \multirow{2}{*}{$\frac{\mathbf{P}}{>0,05}$} \\
\hline \multirow{2}{*}{$\begin{array}{c}\text { Tình trạng } \\
\text { di căn }\end{array}$} & $\begin{array}{l}\text { Di căn nguyên } \\
\text { phát }\end{array}$ & & & & & & \\
\hline & Tái phát di căn & $19(95 \%)$ & $1(5 \%)$ & & $16(80 \%)$ & $4(20 \%)$ & \\
\hline \multirow{2}{*}{$\begin{array}{l}\text { Tiền sử điêu } \\
\text { trị Platinum }\end{array}$} & Không & $14(73.7 \%)$ & $5(26.3 \%)$ & \multirow{2}{*}{$>0.05$} & $14(82.4 \%)$ & $3(17.6 \%)$ & \multirow{2}{*}{$>0.05$} \\
\hline & Có & $14(100 \%)$ & $0(0 \%)$ & & $12(85,7 \%)$ & $2(14,3 \%)$ & \\
\hline \multirow{2}{*}{ Di căn phổi } & Không & $14(77,8 \%)$ & $4(22,2 \%)$ & \multirow{2}{*}{$>0,05$} & $13(81,2 \%)$ & $3(18,8 \%)$ & \multirow{2}{*}{$>0,05$} \\
\hline & Có & $14(93,3 \%)$ & $1(6,7 \%)$ & & $13(86,7 \%)$ & $2(13,3 \%)$ & \\
\hline \multirow{2}{*}{$\begin{array}{c}\text { Di căn } \\
\text { gan }\end{array}$} & Không & $21(85,5 \%)$ & $3(12,5 \%)$ & \multirow{2}{*}{$>0,05$} & $20(90,9 \%)$ & $2(9,1 \%)$ & \multirow{2}{*}{$>0,05$} \\
\hline & Có & $7(77,8 \%)$ & $2(22,2 \%)$ & & $6(66,7 \%)$ & $3(33,3 \%)$ & \\
\hline
\end{tabular}




\begin{tabular}{|c|c|c|c|c|c|c|c|}
\hline Di căn & Không & $16(80 \%)$ & $4(20 \%)$ & \multirow{2}{*}{$>0,05$} & $15(78,9 \%)$ & $4(21,1 \%)$ & \multirow{2}{*}{$>0,05$} \\
\hline hạch & Có & $12(92,3 \%)$ & $1(7,7 \%)$ & & $11(91,7 \%)$ & $1(8,3 \%)$ & \\
\hline Di căn & Không & $19(90,5 \%)$ & $2(9,5 \%)$ & \multirow{2}{*}{$>0,05$} & $18(90 \%)$ & $2(10 \%)$ & \multirow{2}{*}{$>0,05$} \\
\hline xương & Có & $9(75 \%)$ & $3(25 \%)$ & & $8(72,7 \%)$ & $3(27,3 \%)$ & \\
\hline \multirow{3}{*}{$\begin{array}{l}\text { Số lượng } \\
\text { di cănn }\end{array}$} & 1 & $15(83,3 \%)$ & $3(16,7 \%)$ & \multirow{3}{*}{$>0,05$} & $15(93,8 \%)$ & $1(6,2 \%)$ & \multirow{3}{*}{$>0,05$} \\
\hline & 2 & $12(85,7 \%)$ & $2(14,3 \%)$ & & $10(71,4 \%)$ & $4(28,6 \%)$ & \\
\hline & 3 & $1(100 \%)$ & $0(0 \%)$ & & $1(100 \%)$ & $0(0 \%)$ & \\
\hline
\end{tabular}

Nhận xét: Trong nghiên cứu chúng tôi có 100\% bệnh nhân trong nghiên cứu điều trị hết 3 chu kỳ. 31 bệnh nhân điều trị hết đủ 6 chu kì chiếm 93,9\%.

Sau 3 chu kì không có bệnh nhân đáp ứng hoàn toàn, đa phần bệnh nhẩn có đáp ứng một phần chiếm $84.8 \%$, bệnh ổn định $12,1 \%$, có $3 \%$ số bệnh nhân bệnh tiển triển. Sau 6 chu kì, 83.9 \% bệnh nhân đáp ứng trong đó 6 bệnh nhân $(19,4 \%)$ đáp ứng hoàn toàn, bệnh ổn định là $12,9 \%, 1$ bệnh nhân bệnh tiến triển sau điều trị 6 chu kỳ chiếm 3,2\%.

Mối liên quan giữa đáp ứng điều trị với 1 số yếu tố được trình bày trong bảng 1 : chúng tôi không quan sát thây mối liên quan giữa tình trạng đáp ứng với các yếu tố: tình trạng di căn, tiền sử điều trị platinum, di căn phổi, gan, xương, hạch, và số lượng cơ quan di căn.

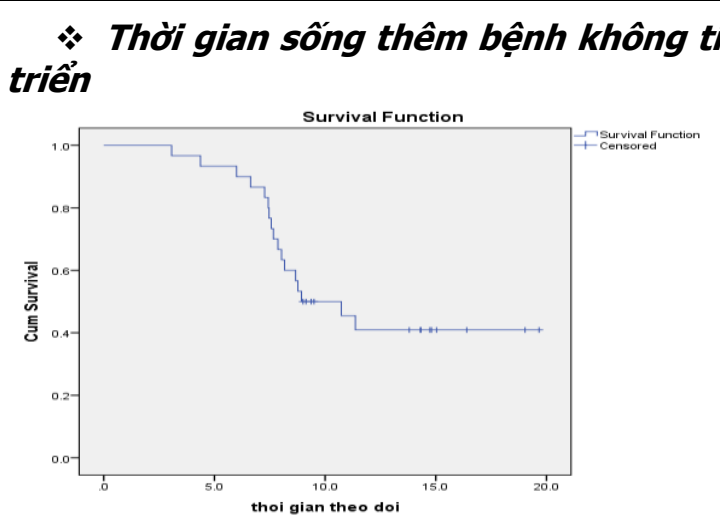

Biểu đồ 1. Sống thêm bênh không tiên triển

Nhân xét: Trung vị sống thêm bệnh không tiến triển của bệnh nhân trong nghiên cứu là 8,9 tháng. Độ tin cậy 95\%: 5,9 - 11,9 tháng.

3.3. Độc tính của phác đồ

\subsubsection{Tác dụng không mong muốn trên hệ tạo huyêt}

Bảng 2. Tác dụng không mong muốn trên hể tạo huyêt

\begin{tabular}{|c|c|c|c|c|c|c|c|c|c|c|}
\hline \multirow{2}{*}{ Tác dung phụ } & \multicolumn{2}{|c|}{ Độ 0 } & \multicolumn{2}{c|}{ Độ 1 } & \multicolumn{2}{c|}{ Đố 2 } & \multicolumn{2}{c|}{ Độ 3 } & \multicolumn{2}{c|}{ Độ 4 } \\
\cline { 2 - 11 } & $\mathbf{n}$ & $\mathbf{\%}$ & $\mathbf{n}$ & $\mathbf{\%}$ & $\mathbf{n}$ & $\mathbf{\%}$ & $\mathbf{n}$ & $\mathbf{\%}$ & $\mathbf{n}$ & $\mathbf{\%}$ \\
\hline Hạ bạch cầu & 12 & 36,4 & 8 & 24,2 & 11 & 33,3 & 2 & 6,1 & 0 & 0 \\
\hline Hạ bạch cầu trung tính & 13 & 39,4 & 6 & 18,2 & 9 & 27,3 & 4 & 12,1 & 1 & 3 \\
\hline Hạ huyết sắc tố & 3 & $9,1 \%$ & 20 & 60,6 & 9 & 27,3 & 1 & 3 & 0 & 0 \\
\hline Hạ tiếu cầu & 18 & 54,5 & 14 & 42,4 & 1 & 3 & 0 & 0 & 0 & 0 \\
\hline
\end{tabular}

Nhận xét: - Tác dụng không mong muốn hay gặp nhất là giảm huyết sắc tố chiếm $90,9 \%$, chủ yểu ở mức độ nhẹ (độ 1, độ 2) chiếm 87,9\%. 1 bệnh nhân hạ độ 3 phải giảm liều hóa chất.

- Giảm bạch cầu chủ yếu gặp ở mức độ nhẹ, có 3\% bệnh nhân có hạ bạch cầu độ 3, thường tự hồi phục sau khi ngừng hóa chất.

- Giảm bạch cầu trung tính gặp ở 63,6\%, thường ở mức độ 1,2. Hạ bạch cầu trung tính độ 3,4 là $15,1 \%$, đa phần hồi phục sau nghỉ hóa chất 7 ngày, 1 bệnh nhân phải giảm liêuu hóa chất.

- Giảm tiều cầu ít gặp hơn, có 45,5\% hạ ở độ 1,2, không gặp độ 3,4.

\subsubsection{Tác dụng không mong muốn ngoài hệ tạo huyết}

\section{Bảng 3. Tác dụng không mong muốn ngoài hể tạo huyêt}

\begin{tabular}{|c|c|c|c|c|c|c|}
\hline \multirow{2}{*}{ Tác dụng phụ } & \multicolumn{2}{|c|}{ Đố 0} & \multicolumn{2}{|c|}{ Đố 1} & \multicolumn{2}{|c|}{ Đố 2} \\
\hline & $\mathbf{n}$ & $\%$ & $\mathbf{n}$ & $\%$ & $\mathbf{n}$ & $\%$ \\
\hline Tăng ALT, AST & 23 & 69,7 & 9 & 27,3 & 1 & 3 \\
\hline Tăng bilirubine & 31 & 93,9 & 2 & 6,1 & 0 & 0 \\
\hline Tăng creatinin & 26 & 78,8 & 7 & 21,2 & 0 & 0 \\
\hline Nôn, buôn nôn & 16 & 48,5 & 9 & 27,3 & 8 & 24,2 \\
\hline ía chảy & 32 & 96,8 & 1 & 3,2 & 0 & 0 \\
\hline
\end{tabular}

- Nôn, buồn nôn là một biến chứng thường gặp với độ 1 chiếm $27,3 \%$ và độ 2 là $24,2 \%$; không có bệnh nhân nôn độ 3,4 biến chứng này

có thể kiếm sát được bằng thuốc.

- Tình trạng tắng men gan, tăng bilirubine mức độ nhẹ, chiếm tỷ lệ nhỏ và tự hồi phục. 
- Có 7 bệnh nhân tăng creatinin độ 1 (21,2\%), trong số đó có 1 bệnh nhân phải chỉnh liều Cisplatin giảm $50 \%$ chu kỳ thứ 4 , và phải chuyển phác đồ sau đó.

- Không gặp trường hợp bệnh nhân sốt hạ bach câu..

\section{BÀN LUẬN}

4.1. Đặc điểm lâm sàng, cận lâm sàng

4.1.1. Đặc điểm về tuổi và giới. Kết quả nghiên cứu này cho thấy tuổi trung bình là 51,6 $\pm 11,1$. Tuổi cao nhất là 70 và thấp nhất là 23 tuổi. Độ tuổi hay gặp nhất là 45-65 chiếm tới $66,7 \%$. Kết quả nghiên cứu ngày có đỉnh tuổi cao hơn nghiên cứu của Li Zhang và cộng sự (2016), Yu Jiang và cộng sự (2005) do khác biệt về vùng dịch tê̂ $[6],[8]$. Đặc điểm về giới cho thây, bênh có tỷ lê mắc cao hơn ở nam giới với tỷ lệ mắc nam/nữ là 9:2. Kết quả nghiên cứu này tương tự với kết quả nghiên cứu của các tác giả khác trên thế giới.

4.1.2. Đặc điểm lâm sàng, cận lâm sàng. Kết quả nghiên cứu của chúng tôi cho thấy, triệu chứng hạch cổ $(39,4 \%)$ thường gặp, các triệu chứng cơ quan di căn ít gặp hơn và có khoảng 30,3\% BN không có triệu chứng, phát hiện di căn qua thăm khám định kỳ. Điều này chứng tỏ vai trò thăm khám định kỳ quan trọng phát hiện bệnh tái phát di căn sau điều trị trước đó.

Tỉ lệ bệh nhân di căn nguyên phát là 39,4\% và tái phát di căn là $60,6 \%$. Tỉ lệ di căn phổi thường gặp nhất chiếm 45,5\%. Tiếp theo là di căn hạch, xương và gan. Di căn một vị trí thường gặp nhất chiếm $83,3 \%$. Kết quả nghiên cứu tương đồng với nghiên cứu của các tác giả trên thế giới. Li Zhang và cộng sự với tỷ lệ di căn phổi là $45 \%$ và tỷ lệ di căn 1 vị trí là $53 \%$ [6]. Hsieh \& CS (2015) tỉ lệ di căn phổi là $38,5 \%$, gan $48,1 \%$, xương $34,6 \%$, di căn xa tại hạch $40,4 \%$, ngoài ra còn gặp di căn phúc mạc, màng phổi, tuyến thượng thận, lách [9].

4.2. Đánh giá kết quả điêu trị. Kết quả nghiên cứu cho thây sau 3, 6 chu kỳ, tỉ lệ đáp ứng lần lượt là $84,8 \%$ và $83,9 \%$, trong đó có 19,4\% bệnh nhân đạt đáp ứng hoàn toàn sau 6 chu kỳ điều trị. Tỉ lệ đáp ứng này cao hơn nghiên cứu trước đó của Li Zhang và cộng sự (2016) với tỷ lệ đáp ứng là $64 \%$, đồng thời cũng cao hơn trong nghiên cứu của Ngan và cộng sự (2002) trong điêu trị bằng gemcitabine - cisplatin tỷ lệ đáp ứng là $73 \%$ [6]. Có sự khác biệt này có thể là do số bệnh nhân trong nghiên cứu của chúng tôi thấp hớn so với các nghiên cứu trên và liên quan tới vùng dịch tễ.
Theo nghiên cứu, không quan sát thấy mối liên quan giữa tỉ lệ đáp ứng phác đồ gemcitabine - cisplatin sau 3 chu kỳ, 6 chu kỳ với tình trang bệnh (di căn nguyên phát hay nhóm tái phát di cằn), vị trí di căn, số lượng vị trí di căn, tuổi và giới. Như vậy, các yếu tố này không là yếu tố tiên lượng đáp ứng với hóa chất điều trị.

Kết quả trung vị thời gian sống thêm bệnh không tiến triển là 8,9 tháng ( $95 \%$ CI: 5,9 -11,9 tháng). Kết quả này tương tự so với các nghiên cứu nước ngoài điều trị phác đồ tương tự: Ngan \& CS (2002) 10,6 tháng, Li Zhang \& CS (2016) 7 tháng[6].

\section{3. Đánh giá độc tính của phác đồ}

Độc tính huyết học. Độc tính của phác đồ chủ yếu trên hệ huyết học là hạ bạch cầu và hạ huyết sắc tố tuy nhiên ít gặp hạ độ 3,4 . Tỉ lệ hạ bạch câu trung tính độ 3-4 gặp ở 15,1\% số bệnh nhân, hạ bạch câu tổng độ 3,4 là $3 \%$. Độc tính hạ huyết sắc tố độ 3-4 gặp ở $0,5 \%$ số chu kỳ và $3 \%$ số bệnh nhân. Độc tính hạ tiểu câu ít gặp. Không bệnh nhân nào sốt do hạ bạch cầu hạt.

Độc tính ngoài huyết học. Trong nghiên cứu có một bệnh nhân phải ngừng điều trị do độc tính thận sau 4 chu kì. Độc tính đường tiêu hóa (nôn, buồn nôn) chủ yếu ở độ 1,2 , không gặp độ 3-4. Các độc tính khác: tăng men gan, tăng bilirubine mức độ nhẹ, chiếm tỷ lệ nhỏ và tự hồi phục.

\section{KẾT LUÂ̂N}

Phác đồ phối hợp gemcitabine - cisplatin trong nghiên cứu của chúng tôi có tỷ lệ đáp ứng cao hơn, trung vị PFS tương tự so với các nghiên cứu về phác đồ gemcitabine - cisplatin trong điều trị ung thư vòm giai đoạn muộn trên thế giới. Kết quả này có thể liên quan đến số lượng bệnh nhân trong nghiên cứu, đặc điểm dịch tễ học bệnh nhân UTVMH tại Việt Nam.

\section{TÀI LIÊU THAM KHẢO}

1. Sung H., Ferlay J., Siegel R.L. và công sứ. (2021). Global Cancer Statistics 2020: GLOBOCAN Estimates of Incidence and Mortality Worldwide for 36 Cancers in 185 Countries. CA A Cancer J Clin, 71(3), 209-249.

2. Lê Vắn Quảng Ung thư vòm mũi họng. Ung thư đâu cổ. Nhà xuất bản Y học, 190-211.

3. Feng B.-J. (2013). Descriptive, Environmental and Genetic Epidemiology of Nasopharyngeal Carcinoma. Nasopharyngeal Carcinoma: Keys for Translational Medicine and Biology. Springer, New York, NY, 23-41.

4. Ong Y.K., Heng D.M., Chung B. và cộng sự. (2003). Design of a prognostic index score for metastatic nasopharyngeal carcinoma. Eur J Cancer, 39(11), 1535-1541. 
5. Toh C.-K., Heng D., Ong Y.-K. và cộng sự. (2005). Validation of a new prognostic index score for disseminated nasopharyngeal carcinoma. $\mathrm{Br}$ ] Cancer, 92(8), 1382-1387.

6. Zhang L., Huang Y., Hong S. và cộng sự. (2016). Gemcitabine plus cisplatin versus fluorouracil plus cisplatin in recurrent or metastatic nasopharyngeal carcinoma: a multicentre, randomised, open-label, phase 3 trial. The Lancet, 388(10054), 1883-1892.

7. Eisenhauer E.A., Therasse P., Bogaerts J. và cộng sự. (2009). New response evaluation criteria in solid tumours: Revised RECIST guideline (version 1.1). European Journal of Cancer, 45(2), 228-247.

8. Jiang Y., Wei Y., Luo F. và cộng sự. (2005). Gemcitabine and Cisplatin in Advanced Nasopharyngeal Carcinoma: A Pilot Study. Cancer Investigation, 23(2), 123-128.

9. Hsieh J.C.-H., Hsu C.-L., Ng S.-H. và công sư. (2015). Gemcitabine plus cisplatin for patients with recurrent or metastatic nasopharyngeal carcinoma in Taiwan: a multicenter prospective Phase II trial. Jpn J Clin Oncol, 45(9), 819-827.

\section{ĐĂC ĐIỂM LÂM SÀNG VÀ HÌNH ẢNH CộNG HƯởNG TỪ CỦA BẾNH VIÊM THI THẦN KINH Ở TRẺ EM}

\section{TÓM TẮT}

Mục tiêu: Mô tả đặc điểm lâm sàng và hình ảnh công hưởng từ của bênh viêm thi thân kinh ở trẻ em. Phương pháp nghiên cứu: Đây là nghiên cứu mô tả cắt ngang, gồm 47 bênh nhân được chẩn đoán và điều trị bệnh viêm thị thần kinh tại Trung tâm thần kinh - Bệnh viện Nhi Trung Ương, trong thời gian 5 năm từ tháng $1 / 6 / 2016$ đến 31/5/2021. Kết quả: 47 bệnh nhân thỏa mãn các tiêu chuẩn lựa chọn, với 83 mắt bị tổn thương. Tuổi trung bình lúc khởi phát bênh là $8,52 \pm 3,1$ tuối. Có 27 bệnh nhân nam và 20 bệnh nhân nữ, tî lệ nam/ nữ là 1,35/ 1. Tại thời điểm khởi phát, có 11 bệnh nhân $(23,4 \%)$ tổn thương một bên mắt, 36 bệnh nhân $(76,6 \%)$ tổn thương 2 bên mắt. Tất cả bênh nhân vào viện vì giảm hoăc mất thị lực, trong đó 22 bệnh nhân $(46,8 \%)$ có tiền sử ho/ sốt trong thời gian 1 tháng trước khởi bệnh. 68 mắt $(81,9 \%)$ có thi lức giảm năng $<1 / 10$ khi vào viên, 48 mắt $(57,8 \%)$ có phù gai thị trên soi đáy mắt. $9 / 47$ bênh nhân $(19,1 \%)$ có các đợt tái phát viêm thị thần kinh. Cộng hưởng từ (CHT) sọ não - ổ mắt cho thấy 10 bênh nhân có tổn thương viêm thi thần kinh hâu nhãn cầu điển hình. Bên cạnh đó, 4 bênh nhân khác có tổn thương chất trắng/ chất xám từ lần đâu khởi bệnh, và 1 bênh nhân trong nhóm này đã tái phát đợt viềm thị thần kinh thứ 2 . Kết luận: Viêm thị thần kinh ở trẻ em có thị lực giảm nặng khi khởi bệnh. CHT sọ não - ổ mắt đóng vai trò quan trọng trong chẩn đoán và tiên lượng diễn biến bệnh. - ổ mắt

Tư khóa: viêm thị thần kinh ở trẻ em, CHT sọ não

\section{SUMMARY \\ CLINICAL AND MAGNETIC RESONANCE IMAGING FEATURES OF PEDIATRIC OPTIC NEURITIS}

\footnotetext{
* Trường Đại hoc Y Hà Nội

** Bênh viện Nhi Trung Ương

Chịu trách nhiệm chính: Đào Thị Việt Hường

Email: dothanhhuong@hmu.edu.vn

Ngày nhận bài: 28.9.2021

Ngày phản biên khoa hoc: 29.9.2021

Ngày duyệt bài: 4.10 .2021
}

Objectives: Clinical and magnetic resonance imaging features of pediatric optic neuritis. Method: This is a cross-sectional study including 47 patients with optic neuritis in the Neurology Centre of National Children's Hospital, for a period of 5 years from June, $1^{\text {th }}, 2016$ to May, 31 ${ }^{\text {th }}, 2021$. Results: 47 patients with 83 affected eyes. Mean age of onset was 8,52 \pm 3,1 . There were 27 male patients and 20 female patients. Male/ female ratio was 1,35/1. 11 patients $(23,4 \%)$ had unilateral involvement, and 36 patients $(76,6 \%)$ had bilateral involvement. All patients admitted to the hospital because of reduced or lost vision, 22 patients $(46,8 \%)$ had viral prodrome during one month before the onset of disease. 68 eyes $(81,9 \%)$ had a visual acuity lower of $1 / 10$ at the time of initial presentation, 48 eyes $(44,9 \%)$ had optic disc edema. $9 / 47$ patients $(19,1 \%)$ had relapse optic neuritis. Magnetic resonance imaging (MRI) brain orbital showed 10 patients with typical retrobulbar neuritis. In addition, 4 other patients had white/ gray matter lesions from the initial onset, and one patient in this group had a second episode of relapse optic neuritis. Conclusion: Pediatric optic neuritis had poor vision at onset. MRI brain - obital plays an important role in diagnosis and prognosis of disease progression. obital.

Key words: pediatric optic neuritis, MRI brain -

\section{I. ĐẶT VẤN ĐỀ}

Viêm thị thân kinh ở trẻ em là bệnh lý hiếm gặp, thuộc nhóm bệnh hủy myelin mắc phải của hệ thân kinh trung ương, đăc trưng bởi mất thị lực cấp tính hoặc bán cấp, tổn thương thị trường và thị lực màu sắc, tổn thương phản xạ đồng tử hướng tâm, tăng tín hiệu dây thân kinh thị trên phim cộng hưởng từ và giảm tốc độ dẫn truyên trên điện thế gợi kích thích thị giác. Bệnh có thể biểu hiện như một bệnh đơn độc, thường sau một đợt nhiễm virus hoặc tiêm vắc xin, hoặc có thể là biểu hiện của nhóm bệnh hủy myelin tiềm ẩn, như xơ cứng rải rác, viêm tủy thị thân kinh hay viêm não tủy lan tỏa cấp tính [1], [2]. 